\title{
MASYARAKAT MADANI DAN PENDIDIKAN ISLAM (MENGKONSTRUKSI MASYARAKAT MADANI MELALUI PENDIDIKAN ISLAM)
}

\author{
Mohammad Asrori ${ }^{1}$
}

\begin{abstract}
Nowadays, talking about madani society in the modern era is a need that must be realized soon. Modern society who does not have religion will always be worried, fightened, and confuse. Therefore, madani society is a peace solution in diversity. Thus, the main goal of education reform agenda is the establishment of madani society. In other word, upholding the values of the sublime social relationship, such as tolerance, and pluralism is a continuation of upholding the values of civilization. With the award, the willingness to look on the others, however the differences that exists without overbearing each other, opinions or views themselves.
\end{abstract}

Keywords: Madani society, Islamic education.

\section{A. Pendahuluan}

Gagasan masyarakat madani sesungguhnya baru popular di Indonesia, sekitar awal tahun 90-an. Sebenarnya awal konsep ini mulai berkembang di Eropa Barat dengan memiliki akar sejarah awal dalam peradaban masyarakat Barat di abad XVIII, atau kini berusia sekitar 250 tahun. Ide modern tentang Civil Society ini oleh Jonh Locke dan generasi berikutnya digunakan untuk menyelesaikan probem tentang social order yang muncul di akhir abad XVII. Akar pembicarannya adalah dalam konteks tradisi sejarah tentang teori politik dan filsafat sosial Barat meskipun kini menjadi santapan para pengamat. Oleh Karena itu nama-nama pemikir besar bermunculan ketika berbicara mengenai Civil Society, mulai dari Locke, Ferguson, Marx, Hegel, Smith, Tocqueville dan Gramsci. Dalam pemikiran kontemporer, berbagai nama ahli sosial juga menghiasinya, seperti Charles Taylor, Edward Shils, Michael Waltzer, dan Daniel S. Bell, dan yang mengkhususkan istilah Civil Society nama-nama seperti Adam Seligman, Jonh Keane, Robert Hefner, Jonh Hall. Dan berakhir setelah sekian lama seolah-olah

1 Dosen Fakultas Ilmu Tarbiyah Dan Keguruan Universitas Islam Negeri Maulana Malik Ibrahim Malang Jl. Gajayana No. 50 Malang 65144 
terlupakan, kini muncul lagi dalam perdebatan wacana ilmu sosial modern. (Suryadi, 1999: 3)

Selanjutnya wacana mengenai masyarakat madani menjadi sangat populer dan digandrungi di Indonesia. Istilah "masyarkat madani" sebagai penterjemahan dari istilah Civil Society, awalnya diperkenalkan oleh Dato Anwar Ibrahim dalam ceramah Simposium Nasional yang diselenggarakan dalam rangka pertemuan ilmiah Festival Istiqlal 26 September 1995 di Jakarta. (Anwar Ibrahim, dalam Aswad Mahasin, 1996: 240). Kemudian konsep tersebut dipopulerkan oleh Nur Cholis Majdid (Pidato Halal Bihalal 28 Januari 1999) dan istilah masyarakat madani sekarang tampaknya sudah baku berkat tingginya sirkulasi penggunaan istilah tersebut.

\section{B. Pengertian Masyarakat Madani}

Kata "madani" berasal dari bahasa Arab yang artinya civil atau civilized (beradab). Tamaddun berati civilization, peradaban. Istilah masyarakat madani adalah terjemahan dari Civil Society atau Civilized Society (dalam Kamus, civil juga bisa berati cilivized). (Echols dan Shadily, 1996: 115)

Muhammad HR. Songge menjelaskan bahwa Civil Society atau masyarakat madani adalah suatu bentuk masyarakat yng mandiri, sederajat, setara, demokratis, berkeadilan, dan menjunjung tinggi nilainilai kemanusiaan. (Songe, 2001: 16) Hal ini sangat sejalan dengan konsep Nurcholis Madjid mengenai masyarakat madani atau berperadaban seperti yang dicontohkan oleh Nabi SAW selama sepuluh tahun di Madinah. Beliau membangun masyarakat yang adil, terbuka, dan demokratis dengan landasan taqwa kepada Allah SWT dan berlandaskan ajaran-Nya, atau dalam peristilahan lain disebut mempunyai semangat rabbaniyah atau robbiyah. Inilah hablum minallah, tali hubungan dengan Allah.

Semangat rabbaniyah jika cukup tulus dan sejati akan memancarkan semangat perikemanusiaan atau masyarakat yang berbudi luhur dan berakhlak mulia. Inilah yang disebut masyarakat berperadaban, masyarakat madani (civil society). (Madjid, 2000: 4)

Oleh karena itu, masyarakat madani yang dibangun Nabi itu, oleh Robert N. Bellah seorang ahli sosiologi agama terkemuka disebut sebagai 
masyarakat yang untuk zaman dan tempatnya sangat modern. Bahkan terlalu modern, sehingga setelah Nabi sendiri wafat kondisi ini tidak bisa bertahan lama. Timur Tengah pada saat itu belum siap dengan prasarana sosial yang diperlukan untuk menopang suatu tatanan sosial modern yang dirintis Nabi. (Bellah, 1976: 150-151)

Masyarakat madani warisan Nabi itu bercirikan antara lain: egalitarisme, memberikan penghargaan kepada orang prestasi (bukan prestise seperti keturunan, kesukuan, atau ras). Keterbukaan, partisipasi seluruh anggota masyarakat dan penentuan kepemimpinan melalui pemilihan, bukan berdasarkan keturunan hanya berlangsung selama tiga puluh tahun sebagaiamana pada masa Khulafaurrasyidin. (Madjid, 1996: 5)

Dari beberapa pengertian diatas dapatlah dipahami bahwa masyarakat madani adalah masyarakat yang dapat menghargai kemanusiaan, menjunjunh tinggi rasa humanisme, berbudi pekerti baik, toleransi, egalitarisme, serta pluralisme.

Berbicara masyarkat madani di zaman modern seperti saat ini adalah merupakan satu kebutuhan yang tidak bisa ditawar lagi untuk segera direalisasikan. Situasi semacam ini oleh karena disebabkan masyarkat modern yang hampa agama akan selalu gelisah, cemas dan serba bingung oleh karena itu, menurut Thohir Luth masyarakat madani merupakan solusi damai dalam perbedaan. (Luth, 2002) Dengan demikian, tujuan utama agenda reformasi pendidikan adalah terwujudnya masyarakat madani. Dengan kata lain tegaknya nilai-nilai hubungn sosial yang luhur, seperti toleransi, dan pluralisme merupakan kelanjutan dari tegaknya nilai-nilai keadaban. Dengan penghargaan, kesediaan memandang yang lain dengan penghargaan, betapapun perbedaan yang ada tanpa saling memaksakan kehendak, pendapat atau pandangan sendiri. (Madjid, 1996: 11)

\section{Telaah Teoritis Konsep Sosiologi Masyarakat Madani}

Dalam perkembangan pembicaraan Civil Society, Amerika Serikat dijadikan model sebagai bentuk Civil Society, hal ini disebabkan karena di Amerika Serikat kekuasaan negara sangat terbatas dan tidak bisa mengintervensi hak-hak individu (biasa disebut dengan small stateness). Meskipun Amerika Serikat merupakan model Civil Society, namun tidak 
berati bebas kritik, sehingga pelaksanaan Civil Society yang ideal tidak lepas sama sekali dari hambatan di Amerika Serikat sendiri. Justru kritik terhadap Amerika Serikat muncul dari orang Amerika Serikat sendiri. Salah satunya adalah kritik dari John K. Galbraith ketika ia berbicara mengenai "the good society", oleh karena ada anggapan bahwa masih banyak ketimpangan terjadi di Amerika Serikat jika dipandang dari sudut ideal. (John Kenneth Galbraith, 1996)

Adam Seligman mengemukakan dua penggunaan istilah Civil Society dari sudut konsep sosiologis: yaitu, dalam tingkatan kelembagaan atau organisasi sebagai tipe sosiologi politik dan membuat Civil Society sebagai suatu fenomena dalam dunia nilai dan kepercayaan. (Adam Seligman, 1992: 203) Untuk yang pertama, Civil Society dijadikan sebagai perwujudan suatu tipe keteraturan kelembagaan. Dalam pengertian ini Civil Socieity dijadikan jargon untuk memperkuat ide demokrasi, yang menurut Seligman dikembangkan oleh T.H. Marshall. Dalam arti berbicara tentang Civil Society sama artinya dengan berbicara tentang demokrasi yang mempunyai karakteristik, sebagaimana Seligman mengutip dari Robert Dahl dan Arend Lijphart, ada delapan :

"(1) the freedom to form and join organiztions, (2) freedom of expression, (3) the right to vote, (4) eligility for public office, (5) the bright of politicial leaders to complete for support and votes, (6) alternative sources of information (what we whould call a press), (7) free and fair elections, and (8) institutions for making government policies depend on votes and other expression of preference". (Adam Seligman, 1992: 203-204)

Kalau yang pertama Civil Society merupakan obek kajian dalam dunia politik (ilmu politik, sosiologi politik, antropologi politik dan social thoughts), maka yang kedua Civil Society menjadi wilayah kajian filsafat yang menekankan pada nilai dan kepercayaan. Untuk yang kedua, menurut Seligman, kajian Civil Society sekarang ini mengarah pada kombinasi antara konsep Durkheim tentang moral individualisme dan konsep Weber tentang rasionalitas bentuk modern organisasi social: atau sintesa Talcott. (Adam Seligman, 1992: 204) Tentang individualism ini John Hall tidak setuju dengan Seligman, sebab Civil Society berbeda dengan individualism. Bahkan menurut Hall, Durkheim sendiri adalah "illiberal thinker". Sedangkan tokoh yang lebih tepat untuk predikat liberalism ini adalah Montesquieu dan Tocqueille yang mempunyai anggapan bahwa "the people can be trusted to rule themselves". (John A. Hll, 1995: 26-27) 
Melihat dari sisi agama Islam, Al-Qur'an menyebut adanya dua macam masyarakat pada masa Nabi Muhammad SAW. Pertama, masyarakat badui atau nomaden yang kehidupannya mengembara dan praktis belum membentuk suatu masyarakat yang menetap (salah satu ciri masyarakat adalah hidup dalam suatu batas wilayah tertentu dan karena itu merasa dirinya satu atau menyatu). Kedua, masyarakat madani, yang telah menetap di suatu tempat tertentu dan merasa dirinya menjadi bagian dari suatu kesatuan. Keadaan menetap tersebut memungkinkan mereka menyepakati suatu tata cara hidup tertentu, yang oleh Rousseau disebut le contract sociale atau perjanjian kemasyarakatan.

Pembagian masyarakat oleh Al-Qur'an tersebut barangkali akan menjadi lebih jelas jika diterangkan dengan teori Civil Society, suatu istilah yang pertama diperkenalkan oleh Cicero, seorang sastrawan dan orator Romawi (106-43 SM) dengan istilah civilis societas. Istilah tersebut dapat diartikan dua. Pertama, suatu masyarakat yang hidup dalam dan memiliki budaya politik atau budaya kekuasaan (civilized political community) dengan perkataan lain disebut dengan sebuah "negara". Kedua, adalah lembaga, kode dan pengaturan sosial serta ekonomi, di luar atau tidak merupakan bagian dari negara. Dua makna itu memang menimbulkan kebingungan dan kerancauan pemikiran hingga sekarang ini. Namun demikian, lebih logis untuk mengikuti makna yang kedua, karena dirasa lebih bisa membedakan antara pengertian tentang "negara" dan "masyarakat" sehingga sangat bermanfaat dalam membuat analisis terhadap berbagai gejala politik dan kemasyarakatan. (Dawam Rahardjo, 1999: 123)

Selanjutnya, dijelaskan dalam bukunya yang terkenal Essay on the History of Civil Society, Adam Ferguson menjelaskan beberapa ciri Civil Society sebagai berikut: (1) masyarakat yang hidup di kota (konsentrasi Pemukiman) dan cara hidup orang kota (2) memiliki kode hukum atau perundang-undangan sebagai dasar pergaulan sosial, ekonomi dan politik (3) memiliki prilaku yang berdasarkan kesopanan, mempertimbangkan yang patut atau tidak patutnya sesuatu yang dilakukan, menghindarkan diri dari sikap dan prilaku yang tercela, menghormati orang lain dan memperhalus ucapan (4) melakukan kerja sama antar sesama warga masyarakat berdasarkan berbagai aturan dan pranata yang disepakati. Dengan perkataan lain, "masyarakat madani" adalah masyarakat yang berkeadaban dan berbudaya, masyarakat yang mampu mengatur dirinya sendiri, yang pada masa-masa lalu disebut sebagai masyarakat 
kota dengan memiliki pola hidup dan sifat-sifat perkotaan (urbanity), kondisi ini sejalan dengan pengertian al-madinah yang berarti "kota". (Dawam Rahardjo, 1999: 124)

Dari penulusuran kata "masyarakat madani" dan Civil Society di atas baik secara terminologis maupun histories, penulis berpendapat bahwa, dalam konteks histories masing-masing memiliki konteks sejarah yang berbeda. Meskipun demikian semangat yang dibawa oleh kedua istilah tersebut secara substansial adalah sama, yaitu berupaya membangun dan membina masyarakat yang plural, demokratis, damai, saling menghormati dengan landasan hukum, hak dna tanggung jawab bersama sehingga terbentuk masyarakat yang tamaddun atau berperadaban. Zamakhasyari Dhofier mengartikan tamaddun sebagai masyarakat yang maju, stabil, mandiri, demokratis, adil dan kompetitif, dan mengandalakan kualitas pendidikan yang tinggi dalam berbagai jenis keilmun dan ketrampilan. (Zamachsjari Dhofier dalam Ismail SM, 2000: 150)

Dari berbagai persepektif tentang masyarakat madani sebagaimana tersebut di atas, dapatlah ditarik benang merah bahwa ciri dan karakteristik masyarakat madani paling tidak memuat hal-hal sebagai berikut :

1. Adanya ruang publik (publik spere) yang bebas bagi masyarakat (warga negara) untuk menyalurkan gagasan dan pendapat, kreatifitas berkarya baik melalui individu-individu, perkumpulanperkumpulan maupun melalui media informasi.

2. Adanya pola kehidupan yang demokratis, artinya warga dalam berperilaku selalu santun melalui interaksi-interaksi sosial tanpa ada perasaan terikat dan tertekanan dari pihak manapun, tetapi prilaku itu muncul berangkat dari kesadaran diri sendiri yang tinggi.

3. Bersikap toleran dalam kehidupan masyarakat yang penuh dengan keanekaragaman pola aktivitas kehidupan.

4. Selau mencerminkan sikap yang pluralisme dengan mengedepankan perilaku yang berkeadaban, sehingga tercipta suasana kehidupan yang aman dan damai.

5. Menjunjung tinggi nilai-nilai HAM dan nilai-nilai keadilan, guna terciptanya keseimbangan dalam kehidupan bermasyarakat. 


\section{Membangun Masyarakat Madani Melalui Pendidikan Islam}

Membangun masyarakat madani agar terbentuk karakteristik sebagaimana tersebut di atas, tidaklah semudah seperti membalikkan telapak tangan semata. Sebaliknya dalam membangun masyarakat madani diperlukan sebuah proses sosialisasi yang panjang, melalui suatu prosess pendidikan. Karena sesungguhnaya, masyarakat madani secara subtansinya adalah terciptanya kehidupan masyarakat yang penuh dengan kecerdasan, kreatifitas (life skill), keadaban, kejujuran, keadilan, keterbukaan, dan penuh dengan nilai-nilai yang bersumber religuisitas. Oleh karena itu, membangun masyarakat madani berarti membangun sikap dan prilaku masyarakat agar tercipta keseimbangan hidup jasmani dan ruhani dalam hidup masyarakat, berbangsa dan bernegara. (Dhohar, 2003: 167) Berkaitan dengan hal ini, salah satu alternatif yang ditawarkan adalah dengan cara pemberdayaan/ memberdayakan warga (rakyat) melalui proses pendidikan, dengan memperhatikan empat pilar utama pendidikan yaitu learning to know, learning to do, learning to be, learning to life together.

Secara sederhana pendidikan Islam dapat diartikan sebagai usaha sadar yang dilakukan secara sistematik untuk membentuk masyarakat didik sesuai dengan tuntutan Islam. (Abuddin Nata, 2003: 129) Paradigma pendidikan Islam pada hakekatnya adalah proses penanaman dan pewarisan nilai-nilai budaya Islam untuk memperdayakan dan atau mengembangkan potensi, serta sekaligus proses produksi nilai-nilai budaya Islam baru sebagai hasil interaksi potensi dengan lingkungan zaman yang terus maju ke depan dan berkembang dalam setiap lini kehidupan. Oleh karena itu, kunci keberhasilan umat Islam agar mampu menangkap ruh ajaran Islam yang sesungguhnya dan selalu konteks dengan kehidupan adalah melalui proses pendidikan. Fazlur Rahman mengatakan bahwa setiap reformasi dan pembaharuan dalam Islam harus dimulai dengan pendidikan. (Fazlur Rahman, 2003: 44-46) Mastuhu juga berpendapat bahwa manusia adalah makhluk yang memiliki daya akal dan kehidupan, maka ia harus membentuk peradaban dan memajukan kehidupan melalui proses pendidikan (belajar mengajar). (Mastuhu, 1994: 4)

Seiring dengan ini, proses pembangunan di Indonesia bertujuan untuk membangun manusia Indonesia seutuhnya, moral dan material. Membangun manusia yang bermoral berarti membangun kualitas 
bangsa. John Gardner mengatakan bahwa suatu bangsa akan menjadi besar apabila bangsa itu percaya pada sesuatu, dan sesuatu itu harus berdimensi moral, sesuatu itu tidak lain adalah agama. Agama akan membentuk manusia bermoral apabila dilakukan melalui jalur proses pendidikan. Pendidikan Islam di Indonesia sebagai sub sistem pendidikan nasional, pada hakekatnya juga bertujuan untuk berpartisipasi dalam membangun kualitas bangsa dalam segala aspeknya, terutama sekali dalam hal peningkatan moral. (Nurcholis Madjid, 1993: xx)

Pendidikan Islam di Indonesia dewasa ini mendapat sorotan tajam dari masyarakat. Sebagian pengamat pendidikan mengatakan bahwa krisis multidimensional yang melanda masyarakat Indonesia selama ini, terutama krisis moral dan kepercayaan adalah disebabkan karena kegagalan dalam membina masyarakat, khusunya masyarakat peserta didik untuk menjadi insan yang beriman dan bertakwa, mampu mencegah umat islam dari praktek-praktek kolusi, korupsi dan nepotisme yang didorong oleh sikap hidup konsumeristik, materialistik dan hedonistik. (Zamachsahari Dhofier, 2000: 146)

Secara teoritis pendidikan Islam sangat besar peranannya dalam membentuk masyarkat. Hal ini dapat dijelaskan melalui analisis sebagai berikut :

Pertama, dilihat dari segi tujuannya, pendidikan Islam memiliki tujuan yang berkaitan dengan pembinaan masyarakat yang beradab. Athiyah al-Abrasyi mengatakan bahwa pendidikan akhlak adalah mendidik jiwa dan merupakan tujuan pendidikan Islam. Tetapi ini tidak berarti bahwa kita tidak mementingkan pendidikan jasmani dan akal atau ilmu atau segi-segi praktis lainnya. (Moh. Athiyah al-Abrasyi, 1974: 15) Tentang terbentuknya akhlak yang mulia sebagai tujuan utama pendidikan Islam telah pula dikemukakan oleh tokoh-tokoh pendidikan Islam lainya. Ibnu Miskawaih (932-1030 M) misalnya mengatakan bahwa tujuan pendidikan Islam adalah terwujudnya sikap bathin yang mampu mendorong secara spontan untuk melahirkan semua perbuatan yang bernilai baik. (Ibn Miskawih, 1979: 34-35) Sementara itu al-Qabisi (936-1012 M) mengatakan bahwa tujuan pendidikan Islam adalah menumbuh-kembangkan pribadi anak sesuai dengan nilai-nilai Islam yang benar. (Ali al-Jumbulati, 1994: 87) Demikian pula Ibnu Sina (980-1037 M) berpendapat bahwa tujuan pendidikan Islam dalam mengembangkan seluruh potensi yang dimiliki seseorang ke 
arah perkembangannya yang sempurna, yaitu perkembangan fisik, intelektual dan budi pekerti. (Ibn Sina, 1906: 176)

Dari berbagai pendapat para ahli pendidikan tersebut di atas, dengan jelas dapat diketahui bahwa tujuan utama pendidikan Islam adalah mewujudkan manusia yang berakhlak mulia, di samping mencerdaskan akal pikiran dan ketrampilannya. Dengan cara demikian akan lahir manusia-mausia yang pandai, terampil namun berakhlak mulia. Manusia-mausia yang demikian itulah yang diharapkan dapat membangun masyarakat madani.

Kedua, dilihat dari sifatnya, pendidikan Islam tidak memisahkan antara pengajaran dan pendidikan. Pengajaran biasanya diartikan sebagai kegiatan mengisi otak anak dengan ilmu pengetahuan (transfer of knowledge) sedangkan pendidikan adalah membina attitude, kepribadian atau sikap. (M. Quraish Shihab, 1994: 145) Pengajaran dan pendidikan tidak dapat dipisahkan. Pengajaran ilmu nahwu misalnya meangandung pendidikan, yaitu untuk membantu manusia agar lurus dalam berbicara. Demikian pula pelajaran ilmu manthiq (logika) mengandung pandidikan, yaitu untuk membantu manusia agar lurus dalam berfikir. (Ibn Miskawih, 1979: 64) Demikian pula pengajaran matematika mengandung pendidikan, yaitu untuk merangsang pertumbuhan nilai-nilai kejujuran, ketelitian dan keuletan bekerja. Selanjutnya dalam pengajaran sejarah juga mengandung pengajaran agar maenumbuhkan kebiasaan meniru yang baik dan meninggalkan perbuatan yang buruk.

Ketiga, dilihat dari segi pendidik / guru, pendidikan Islam menghendaki agar seorang guru di samping memiliki pengetahuan yang mendalam dan luas tentang ilmu yang akan diajarkannya, juga harus mampu menyampaikan ilmunya itu secara efektif da efesien, serta memiliki akhlak yang mulia. Imam al-Ghazali mengatakan bahwa seorang guru yang menyampaikan ilmu pengetahuan harus berhati bersih, berbuat dan bersikap terpuji. (Imam al-Ghozali, 48-49) Lebih lanjut, al-Ghazali menyatakan bahwa seorang guru harus bersikap sebagai pengayom, bersikap kasih sayang terhadap murid-muridnya dan hendaknya memperlakukan mereka seperti anaknya sendiri. Guru harus selalu mengontrol, menasehati, memberikan pesan-pesan moral tentang ilmu dan masa depan anak didiknya dan tidak membiarkan mereka melanjutkan pelajarannya kepada yang lebih tinggi sebelum mereka 
menguasai pelajaran dan memiliki akhlak yang mulia. Keseimbangan perkembangn keilmuan (akal) dan akhlak (prilaku hati) merupakan hal yang harus selalu dikontrol oleh guru. (Imam al-Ghozali, 48-49) Guru yang demikian itulah yang selain menumbuhkan kecerdasan akal pikiran, juga dapat menumbuhkan akhlak yang mulia sehingga mampu menghasilkan produk generasi bangsa yang cakap dalam berfikir, cerdas dalam berkarya dan matang dalam bersikap/ berperilaku..

Keempat, dilihat dari segi pengajarannya, pendidikan Islam bisa ditempuh dengan cara menyampaikan (materi) pengajaran dan memberikan contoh sikap tauladan yang sesuai dengan ilmu yang diajarkan, anak didik yang diberi pengajaran, dan lingkungan di mana pengajaran tersebut berlangsung, serta berbagai sarana yang tersedia. Dengan cara demikian, materi pelajaran yang disampaikan akan sesuai dengan kebutuhan anak didik. Dengan kata lain, pendidikan Islam bias diberikan dengan cara-cara pengajaran yang bijaksana, manusiawi (humanis) dan sesuai dengan perkembangan zaman.

Kelima, dilihat dari segi sasarannya, pendidikan Islam ditujukan untuk semua manusia, tanpa membeda-bedakan jenis kelaminnya. Dengan cara demikian, maka semua umat manusia akan memperoleh kesempatan pendidikan yang sama,dan akibatnya mereka akan mendapatkan kemajuan yang sama pula. Apalagi Islam mengajarkan konsep belajar adalah" minal mahdi ila al-lahdi" yaitu bahwa Pendidikan juga berlangsung seumur hidup (life long education)

Keenam, dilihat dari segi lingkungannya, pendidikan Islam menggunakan seluruh lingkungan pendidikan, mulai dari lingkungan rumah tetangga (keluarga), masyarakat sampai dengan sekolah maupun perguruan tinggi. Ketiga lingkungan pendidikan tersebut memiliki tanggung jawab yang sama. (Abuddin Nata, 2003: 132)

\section{E. Penutup}

Bertolak dari uraian di atas, maka dapat dijelaskan bahwa yang dimaksud dengan masyarakat madani adalah:

1. Masyarakat yang beradap,yaitu masyarakat yang seluruh aspek kehidupannya didasarkan pada nilai-nilai ilahiyah yang universal, seperti egaliter, kejujuran, demokratis, manusiawi, kemitraan, dan keikhlasan. 
2. Sesungguhnya untuk mewujudkan keadaan masyarakat yang demikian maka salah satunya adalah dapat dicapai melalui pendidikan Islam, karena pendidikan Islam dengan berbagai aspeknya didasarkan pada nilai-nilai yang luhur dan universal.

3. Selanjutnya merupakan salah satu langkah yang amat strategis juga dalam mewujudkan masyarakat madani adalah dengan melaksanakan pendidikan Islam sesuai dengan sifat dan karakteristiknya.

4. Langkah-langjkah strategis lainnya adalah dengan mewujudkan keteladanan diri para pendidik dan pemimpin masyarakat, menumbuh-kembangkan kebersamaan dan melaksanakan da'wah.

\section{DAFTAR PUSTAKA}

Azra, Azyumardi, 2002. "Menggalang Masyarakat Indonesia Baru" Jurnal Pendidikan Tinggi Agama Islam (PERTA). Vol. V/ No.02/2002.

Al-Abrasyi, Moh. Athiyah , 1974. Dasar-dasar Pendidikan Islam, terj. H.Bustami A.Ghani dan Djohar Bahri LIS. Jakarta: Bulan bintang

Al-Ghazali, Imam. tt.. Ihya' Ulum al-Din, Jilid I, Bairut: Dar al-Kutub

Al-Jumbulati, Ali, 1994. Perbandingan Pendidikan Islam, terj. M. Arifin, dari judul Asli Dirasat al-Muqaranah fi al-Tarbiyah al-Islamiyah, Jakarta: Rineka Cipta

Bellah, Robert N., Ed., 1976. Beyond Belief, New York: Harper And Row, Edisi Paperback

Djohar, 2003. Pendidikan Strategik: Alternatif Pendidikan Masa Depan, Yogjakarta: LESFI

Echols, Jhon M. dan hasan Sadili, 1996. Kamus Inggris-Indonesia. Jakarta: PT. Gramedia

Galbraith, Jhon Kenneth, 1996. The Good Society: The Mumane Agenda, New York: Houghton Miffin Company 
Mohammad Asrori - Masyarakat Madani dan Pendidikan Islam...

Hall, Jhon A., Ed.,1995. Civil Society: Theory, History, Comperation, Cambridge: Polity Press

Ismail, SM, Ed, 2000. pendidikan Islam,Demokratisasi dan Masyarakat madani, Yogjakarta: Pustaka pelajar

Luth, Thohir, 2002. Masyarakat Madani Solusi Damai Dalam Perbedaan, Jakarta: Mediacita

Madjid, Nurcholis, 1993. Islam Dokrin dan Peradaban, Jakarta: Yayasan Wakaf Pramamadina

"Menuju Masyarakat Madani"dalam Jurnal Kebudayaan dan Peradaban Ulumul Qur'an, No. 2/VII/1996

, "Meneruskan Agenda Reformasi untuk Demokrasi dengan Landasan Jiwa Masyarakat madani, Masyarakat Pluralisme dan Toleransi". Artikel tidak dipublikasikan, Pidato Halal Bi Halal KAHMI, Jakarta, 11 Syawal 1419/ 28 Januari 1999 Yang Adil, Terbuka, Demokratis: Serial Khutbah Kontemporer I, Beragama di Abad Dua puluh Satu, Jakarta: Dzikrul Hakim

Mahasin, Aswab, et., 1996. Ruh Islam Dalam Budaya Bangsa, Jakarta: Yayasan Festival Istiqlal

Mastuhu, 1994. Dinamika Sistem Pendidikan Pesantren, Seri XX, Jakarta: INIS

Miskawaih, Ibnu, 1979. Kitab al-Sa'adat, Cairo: Dar al-Thiba'at alMuhammadiyah

Nata, Abudin, 2003. Managemen Pendidikan: Megatasi Kelemahan Pendidikan Islam, Jakarta: Prenada Media

Rahardjo, M., 1999. Masyarakat Madani: Agama, Kelas menengah denan Perubahan Sosial, Jakarta: LP3ES

Rahman, Fazlur, 1984. Islam, terj.Ahsin Muhammad, Bandung: Pustaka

Seligman, Adam, 1992. The Idea Civil Society, New York: The Fre Press

Sina, Ibn., 1906. Al-Siasah fi al-Tarbiyah, Mesir; Majalah Al-Masyrik 
Mohammad Asrori - Masyarakat Madani dan Pendidikan Islam...

Shihab, M. Quraisy, 1994. Membumikan Al-Qur'an, Bandung: Mizan Suryadi, Adi, 1999. Masyarakat Madani, Jakarta: Raja Grafindo

Songe, Muhammad HR., "Masjid dan Masyarakat Madani, Pesan Risalah Masyarakat Madani", No. 11/ Th III/03/2001 
